\title{
Role of long noncoding RNAs in malignant disease (Review)
}

\author{
$\mathrm{YING} \mathrm{LI}^{1}$ and XIN WANG ${ }^{1,2}$ \\ ${ }^{1}$ Department of Hematology, Shandong Provincial Hospital Affiliated to Shandong University; \\ ${ }^{2}$ Department of Diagnostics, School of Medicine, Shandong University, Jinan, Shandong 250021, P.R. China
}

Received April 9, 2015; Accepted November 24, 2015

DOI: $10.3892 / \mathrm{mmr} .2015 .4711$

\begin{abstract}
Long noncoding RNAs (lncRNAs) are endogenous transcribed RNA molecules without protein-coding potential, ranging between 200 and 100,000 nt in length. LncRNAs regulate the expression of specific genes in several ways, including guiding chromatin-remodeling, and affecting splicing, transcription or translation. The mutations and dysregulation of lncRNAs have been found to be important in various human diseases, but particularly in human cancer. Previous studies have demonstrated that changes to lncRNAs are closely associated with tumorigenesis, metastasis, prognosis and diagnosis. The current review aims to present a brief overview of the associated reports of lncRNAs in malignant neoplasms, including breast cancer, prostate cancer and hematological malignancies. LncRNAs may be evaluated as novel markers in disease diagnosis, and as prospective therapeutic targets for the prevention and treatment of human diseases.
\end{abstract}

\section{Contents}

1. Introduction

2. Definition and classification of lncRNAs

3. Biological function of lncRNAs

4. LncRNAs in tumors

5. Conclusion and future perspectives

\section{Introduction}

The regulation of protein-coding genes follows the central dogma: DNA $\rightarrow$ RNA $\rightarrow$ protein. Results of human genome projects indicate that $>90 \%$ of the genome is transcribed into RNA, only $1.5-2.0 \%$ of the genome encodes protein-coding genes, and the remainder are noncoding RNAs (ncRNAs), which were once considered to be transcriptional noise (1).

Correspondence to: Professor Xin Wang, Department of Hematology, Shandong Provincial Hospital Affiliated to Shandong University, 324 Jingwu Road, Jinan, Shandong 250021, P.R. China E-mail: xinw007@126.com

Key words: long noncoding RNA, cancer, leukemia, lymphoma
The ncRNAs are divided into two major groups based on their length: Small ncRNAs and long ncRNAs (lncRNAs) $(2,3)$. Small ncRNAs (length, <200 nt), including microRNAs (miRs), are important in various cancer processes (4-6). LncRNAs are commonly defined as independent transcriptional units with no significant protein-coding capacity, and are between 200 and 100,000 nt in length. Previous mass-scale transcriptome sequencing has revealed that thousands of IncRNAs are transcribed in large quantities in human and other mammalian genomes (7).

\section{Definition and classification of IncRNAs}

LncRNAs are commonly defined as non-protein-coding RNA molecules of $>200 \mathrm{nt}$. Despite poor conservation of their nucleotide sequences, compared with protein-coding genes, lncRNAs have tissue-specific expression patterns (8). LncRNAs are divided into several subtypes, according to their location with respect to protein-coding genes: i) Sense lncRNAs intersect one or more exons of another transcript on the same strand; ii) antisense IncRNAs have transcripts, which overlap with one or more exons of a protein-coding locus on the opposite strand, and show evidence of antisense regulation of a protein-coding gene (9); iii) intergenic lncRNAs, also designated lincRNAs, do not intersect with any protein-coding loci, and are located between two other genes; iv) intronic lncRNAs are contained completely within protein-coding introns and do not intersect any exons; v) bidirectional lncRNAs share a promoter with another transcript in the opposite strand and are, thus coregulated $(9,10)$.

\section{Biological function of IncRNAs}

With the development of whole genome and mass-scale transcriptome sequencing technologies, the functions of lncRNAs have been investigated in various fields (11-13). Although only a small fraction of lncRNAs identified have been investigated experimentally, an emerging paradigm suggests that lncRNAs function in multiple biological contexts. For example, lncRNAs can also act as scaffolds during the formation of cellular substructures or protein complexes (14-16), and evidence indicates that lncRNAs are involved in regulating gene expression at transcriptional, post-transcriptional and epigenetic levels $(17,18)$, which affect cell differentiation and cycle control $(19,20)$, as well as controling apoptosis and cell death $(21,22)$. 
Transcriptional control is important in the regulation of gene expression in prokaryotes and eukaryotes. It has been demonstrated that lncRNAs modulate large-scale gene expression via interacting with chromatin at numerous different locations across multiple chromosomes (23). It has been determined that IncRNAs can affect transcription via various mechanisms, including altering the activity of specific transcription factors and polymerases, acting as coactivators of transcription factors, binding to DNA or proteins, interacting with RNA binding proteins and inhibiting the promoter of their target gene (24-26).

LncRNAs modulate the expression of mRNA at the post-transcriptional level by affecting mRNA stability and modulating cell cycle distribution and cell differentiation. For example, growth-arrested DNA damage-inducible gene 7 (gadd7), a DNA damage-inducible lncRNA, controls cell-cycle progression $(27,28)$. It is key in the regulation of the $G_{1} / S$ checkpoint following DNA damage (28). UV-induced gadd7 specifically binds to TAR DNA-binding protein (TDP-43), disrupting the interaction between TDP-43 and cyclin-dependent kinase 6 (Cdk6) mRNA, and decreasing the expression of Cdk6 (28). The antisense transcript for $\beta$-site amyloid precursor protein (APP)-cleaving enzyme 1 (BACE1-AS) has been observed to stabilize mRNA, thus, maintaining mRNA expression levels at the post-transcriptional level (29-31). BACE1, also termed $\beta$-secretase- 1 , is a crucial enzyme in the pathophysiology of Alzheimer's disease. Increased expression levels of BACE1 and APP in plaque-associated presynaptic dystrophies increase the generation of local peri-plaque amyloid $\beta(\mathrm{A} \beta)$ and accelerate the growth of amyloid plaque in Alzheimer's disease $(32,33)$. BACE1-AS can regulate BACE1 mRNA and subsequent BACE1 protein expression in vitro and in vivo, and in Alzheimer's disease, the upregulated expression of BACE1-AS increases the stability of BACE1 mRNA and generates additional $\mathrm{A} \beta 1-42$ via a post-transcriptional feed-forward mechanism (29).

The term epigenetics refers to reversible modifications of DNA molecules of one cell or histones, which change the DNA conformation and result in changes to the expression of genes without altering the sequence of bases in the DNA (30). Epigenetic changes, including DNA methylation, histone modification, chromatin remodeling, genome imprinting and the regulatory mechanisms of RNA editing, can affect gene expression $(35,36)$. Aberrations in epigenetic modifications are common in several human diseases, including cancer $(35,37,38)$. DNA methylation, the best-known epigenetic marker, is important in the regulation of a wide variety of molecular processes, including maintaining the stability of the genome and regulating gene expression and inactivation (36). Previous studies have demonstrated that lncRNAs are critical in epigenetic regulation $(39,40)$, and have also indicated that DNA methylation and histone modifications are common epigenetic mechanisms, resulting in the deregulation of lncRNA expression levels in tumors $(41,42)$.

Brannan et al (43) identified H19, a 2.3 kb lncRNA, which can interact with methyl-CpG-binding domain protein 1 (MBD1) that is involved in the maintenance of repressive H3K9me3 histone marks, forming the H19 lncRNA-MBD1 complex and controlling gene expression of the imprinted gene network (IGN) (15). H19 associated with chromatin-modifying complexes provides a method for regulating embryonic growth (15).

\section{LncRNAs in tumors}

Numerous experimental studies and clinical observations have suggested that aberrant lncRNA expression is associated with various human diseases and disorders, particularly in tumors (44-46). Although the precise mechanism underlying how lncRNAs result in the development and progression of cancer remains to be elucidated, previous studies $(15,22,47)$ have linked distinct types of mutations in lncRNA genes with diverse diseases, and have demonstrated that certain lncRNAs serve as tumor suppressors or carcinogenic factors in the development of cancer.

4.1 LncRNAs in lung cancer. Lung cancer is a leading cause of mortality worldwide (48). Non-small cell lung cancer (NSCLC), including adenocarcinoma, squamous cell carcinoma and large cell carcinoma accounts for $80-85 \%$ of new cases of lung cancer (49-52). Evidence indicates that lung cancer metastasis is significantly associated with the noncoding metastasis-associated lung adenocarcinoma transcript 1 (MALAT1) located on chromosome 11q13, which is a highly expressed lncRNA with a length of $>6,500 \mathrm{bp}(53,54)$. The overexpression of MALAT1 results in an increase in cell proliferation and migration in lung cancer, and MALAT1 serves as a novel prognostic marker for survival in NSCLC $(54,55)$.

4.2 LncRNAs in breast cancer. Breast cancer is a common malignancy in females, and its incidence in younger women is increasing. Previous studies have suggest that lncRNAs have a significant correlation with the onset and development of breast cancer $(56,57)$.

HOX antisense intergenic RNA (lincRNA-HOTAIR) is a $2.2 \mathrm{~kb}$ carcinogenic lncRNA, which is located in the mammalian homeobox $\mathrm{C}$ (HOXC) locus on chromosome $12 q 13.13$ (58). HOTAIR acts as a scaffold by combining its 3 ' region with the lysine-specific demethylase 1 (LSD1)/corepressor for element-1-silencing transcription factor/repressor element RE-1 silencing transcription factor complex, and its 5 ' region with polycomb repressive complex 2 (PRC2) (58-60). This acts to regulate histone $\mathrm{H} 3$ methylation at lysine 27 and demethylation at lysine 4 , and silence the HOXD loci in trans (58). PRC2 is a protein responsible for $\mathrm{H} 3 \mathrm{~K} 27$ methyltransferase, and is associated with developmental gene silencing and cancer progression (58-61). LSD1 is a histone methyltransferase, which mediates the enzymatic demethylation of H3K4Me2 (62). The increased expression levels of HOTAIR have been associated with poor prognosis and tumor metastasis in breast cancer $(58,63)$, and Gupta et al $(63)$ demonstrated that the expression levels of HOTAIR in the primary tumor and metastases were significantly increased, compared with non-cancerous tissues. The systematically dysregulated HOTAIR results in increased in vitro cell invasion and in vivo metastasis in breast cancer cells (63-65). The genome-wide reorientation of PRC2, caused by enforced HOTAIR expression in epithelial cancer, leads to altered histone H3 lysine 27 methylation and gene expression, which can increase the cancer invasiveness and metastasis, in a PRC2-dependent 
manner (63). Decreased levels of HOTAIR markedly reduce cancer invasiveness, particularly in cells with increased PRC2 activity (63).

LncRNA-LOC554202 is another lncRNA, which is important in the development and progression of breast cancer $(66,67)$. Compared with normal breast tissue, the expression level of IncRNA-LOC554202 in breast cancer tissues is significantly upregulated, and is correlated with tumor size and advanced pathological stage (66). Small interfering (si)RNA-mediated knockdown of LOC554202 results in a significant accumulation of cells at the $G_{0} / G_{1}$-phase $(P<0.05)$ and a marked decrease in cells in S-phase. This indicates that siRNA-mediated knockdown of IncRNAs-LOC554202 inhibited breast cancer proliferation, invasion and migration, and increased apoptosis in vitro and prevent tumorigenesis (66).

LncRNAs are important in modulating the occurrence and development of cancer, reinforcing the potential of identifying a novel type of targeted therapy to diagnose, treat and prevent breast cancer effectively. Further investigations to identify lncRNA markers with higher sensitivity and specificity in breast cancer-associated lncRNAs is required, as are investigations aimed at reducing the occurrence of breast cancer by regulating the expression of specific lncRNAs that affect transcription of tumor suppressor genes.

\subsection{LncRNAs in prostate cancer $(P C a)$. Previous studies $(68,69)$} have demonstrated that the abnormal expression of genes regulated by $\operatorname{lncRNAs}$ are associated with PCa. Studies have indicated that lncRNAs are involved in cell proliferation, cell invasion and metastasis by functioning as oncogenes or as tumor suppressor genes, and IncRNAs associated with PCa have been identified, including PCA3 and PCAT1 (70,71).

PCA3 is a well-investigated 1ncRNA in PCa $(72,73)$. Compared with normal prostate tissue, the expression levels of PCA3 have been found to be upregulated 66-fold in PCa tissue, and this overexpression was observed in $>95 \%$ of primary and metastatic PCa specimens (73). PCA3 has been used as a biomarker for molecular diagnostics in clinical urological practice (72,73). PCa associated ncRNA transcript-1 (PCAT-1) is a highly prostate-specific lncRNA, which is markedly overexpressed in a subset of PCa and promotes cell proliferation (69). Crea et al (74) observed that a novel lncRNA, PCAT18, was specifically expressed in the prostate. PCAT18 silencing can markedly inhibit PCa cell proliferation, and inhibit tumor cell migration and invasion (74). Together, this suggests that lncRNAs may act as novel therapeutic targets in $\mathrm{PCa}$ and as biomarkers for metastatic PCa.

\subsection{LncRNAs in hematological malignancies}

4.4.1 LncRNAs in acute leukemia. Leukemia is one of the most common types of malignant tumor. In previous years, miRs have been well described in hematological malignancies, while lncRNAs are expected to be increasingly investigated.

Maternally expressed gene 3 (MEG3) is an imprinted gene located at 14q32, which encodes an IncRNA correlated with several types of human cancer (75,76). MEG3 is also expressed in various normal tissues and functions as an IncRNA tumor suppressor. The loss of MEG3 expression in tumors occurs as a result of gene deletion, promoter hypermethylation and hypermethylation of the intergenic differentially methylated region (76). It was shown to activate p53 and facilitate p53-dependent or independent pathways, functioning as a tumor suppressor (77). Benetatos et al (78) observed that MEG3 was abnormally methylated in patients with acute myelogenous leukemia (AML) and myelodyplastic syndrome, and MEG3 hypermethylation was associated with significantly reduced overall survival rates in individuals with AML. The MEG3 methylation status may serve as a useful biomarker in leukemia.

T-cell acute lymphoblastic leukemia (T-ALL) is an agressive hematological malignancy $(79,80)$. T-ALL-R-LncR1, is a novel long non-coding RNA associated with apoptosis regulation in T-ALL cells, and is prominently expressed in certain tumor tissues, but not detected in normal human tissues (80). T-ALL-R-LncR1 knockdown induced the formation of a prostate apoptosis response-4/THAP protein complex, enhance the activation of caspase-3, and accelerated apoptosis in Jurkat cells $(80,81)$. Therefore, suppressing RNA T-ALL-R-LncR1 may be a potential therapeutic strategy in human T-ALL.

Two novel lncRNAs have been identified in acute promyelocytic leukemia cells, HOX antisense intergenic RNA myeloid 1 (HOTAIRM1) and HOXA cluster antisense RNA 2 (HOXA-AS2) (82-84). HOTAIRM1 and HOXA-AS2 are upregulated in NB4 promyelocytic leukemia cells $(82,83)$. HOTAIRM1 is a small intergenic transcript from the plus (opposite) strand between the HOXA1 and HOXA2 genes, and shows myeloid-specific expression (84). It is involved in myelopoiesis through modulation of gene expression in the HOXA cluster (84). Knockdown of HOTAIRM1 quantitatively decreases RA-induced expression of HOXA1 and HOXA4 during the myeloid differentiation of NB4 cells, and selectively attenuates the expression of myeloid differentiation genes, cluster of differentiation (CD)11b, CD11c and CD18 (82,84), but does not affect the more distal HOXA genes (83). HOXA-AS2 is located between HOXA3 and HOXA4 within the HOXA cluster in the human genome, and is transcribed in the opposite direction. It functions as an apoptosis repressor in all trans RA (ATRA)-treated NB4 cells via mechanisms mediated, in part, by tumor necrosis factor-related apoptosis-inducing ligand, which is a prominent biologically-targeted anti-tumor protein due to its induction of apoptosis in a variety of human cancer cell lines, avoiding normal cells (85). Knockdown of HOXA-AS2 decreases the number of viable cells and increases the proportion of apoptotic cells, and HOXA-AS2-mediated negative regulation contributes to the fine-tuning of apoptosis in the myeloid differentiation induced by ATRA in NB4 cells (83).

LncRNA-IRAIN is another novel antisense ncRNA, $5.4 \mathrm{~kb}$ in length, with no large open reading frames (86). It is located in the insulin-like growth factor type I receptor (IGF1R) locus (86). IRAIN is expressed exclusively from the paternal allele, while the maternal counterpart is silenced as demonstrated by Sun et al (86) on investigating the underlying mechanism of IGF1R dysregulation in tumors. IGF1R is an abundantly phosphorylated receptor tyrosine kinase, which promotes cell growth via the phosphatidylinositol-4,5-bisphosphate 3-kinase/Akt signaling pathway (86-88). IGF1R regulates multiple cellular functions in tumors, including cellular survival, growth, tumor neovascularization and metastasis $(89,90)$. IRAIN is transcribed in an antisense direction from an intronic promoter, and is downregulated in leukemia cell lines and in patients with high-risk AML (86). Knockdown of IRAIN lncRNA with small hairpin 
Table I. Types of cancer associated with lncRNAs.

\begin{tabular}{|c|c|c|c|}
\hline LncRNA & Cancer & Cytoband & References \\
\hline ANRIL & Prostate, leukemia, gastric & $9 \mathrm{p} 21.3$ & $(102-104)$ \\
\hline Anti-NOS2A & Brain & $17 \mathrm{q} 23.2$ & $(105)$ \\
\hline BC200 & Breast, cervical, esophageal, lung, ovarian, parotid, tongue & $2 \mathrm{p} 21$ & $(106-108)$ \\
\hline GAS5 & Prostate, colorectal, renal cell, breast, pancreatic, lymphoma & $1 \mathrm{q} 25.1$ & $(109-113)$ \\
\hline HOTAIR & Prostate, bladder, kidney, breast, lung, gastric adenocarcinoma, colon & $12 \mathrm{q} 13.13$ & $(114-118)$ \\
\hline PlncRNA-1 & Esophageal squamous, prostate carcinoma & 21 & $(119-120)$ \\
\hline H19 & Bladder, lung, liver, breast, esophagus, gastric & $11 \mathrm{p} 15.5$ & $(121-124)$ \\
\hline MEG3 & Gastric, meningiomas, bladder, leukemia & $14 q 32$ & $(76,78,125)$ \\
\hline PCA3 & Prostate & $9 q 21.2$ & $(73)$ \\
\hline FAS-AS1 & Lymphoma & $10 \mathrm{q} 24.1$ & $(42)$ \\
\hline
\end{tabular}

LncRNA, long noncoding RNA; ANRIL, antisense noncoding RNA in the INK4 locus; NOS2A, nitric oxide synthase, inducible; BC200, brain cytoplasmic RNA 1; GAS5, growth arrest-specific 5; HOTAIR, HOX antisense intergenic RNA; PlncRNA-1, CBR3 antisense RNA 1; H19, H19, imprinted maternally expressed transcript; MEG3, maternally expressed 3; PCA3, prostate cancer associated 3; FAS-AS1, FAS antisense RNA 1 .

RNA eliminates the intrachromosomal interaction between chromatin DNA and lncRNA (86).

\subsubsection{LncRNAs in chronic myeloid leukemia. Chronic} myeloid leukemia (CML) is a malignant disease occurring in clonal hematopoietic stem cells, which accounts for $20 \%$ of all adult leukemia cases (91) and is characterized by the clonal hyperproliferation of immature white blood cells. The Philadelphia $(\mathrm{Ph})$ chromosome and/or breakpoint cluster region $(\mathrm{Bcr}) / \mathrm{ABL}$ proto-oncogene $1(\mathrm{Abl})$ gene rearrangement is a specific marker of CML $(91,92)$. The BCR-ABL gene is a fusion gene generated by the $\mathrm{t}(9 ; 22)(\mathrm{q} 34.1 ; \mathrm{q} 11.21)$ translocation, which produces the $\mathrm{Ph}$ chromosome (93). Bcr-Abl-induced tumorigenesis involves the alteration of numerous signaling pathways that regulate cell survival and proliferation, including the PI3K/phosphatase and tensin homolog (PTEN)/AKT, RAS and Janus kinases/signal transducer and activator of transcription signaling pathways (94-97). Altering the expression of the BCR-ABL gene regulates the induction of cellular proliferation, and the inhibition of cellular differentiation and programmed cell death $(98,99)$. Guo et al $(97)$ identified a novel lncRNA, IncRNA-BGL3, which is a key regulator of Bcr-Abl-mediated cellular transformation. LncRNA-BGL3 was found to function as a competitive endogenous RNA for binding the miRs that repress PTEN mRNA, including miR-17, miR-93, miR-20a, miR-20b, miR-106a and miR-106b, to cross-regulate PTEN expression. LncRNA-BGL3 was induced following inhibition of Bcr-Abl kinase activity or disruption of Bcr-Abl expression in K562 cells and leukemic cells derived from patients with CML (97). It has been demonstrated that Bcr-Abl represses the expression of IncRNA-BGL3 via c-Myc-dependent DNA methylation (97), which suggests that regulating the expression of lncRNA-BGL3 may be a potential therapeutic strategy for Bcr-Abl-positive leukemia.

4.4.3 LncRNAs in lymphoma. FAS-AS1 is an lncRNA corresponding to an antisense transcript of Fas, which can tightly regulate the alternative splicing of Fas in lymphomas.
Sehgal et al (42) found that expression levels of FAS-AS1 have a negative correlation with the production of soluble Fas (sFas), and that increased levels of FAS-AS1 decrease the expression of sFas, and eliminate the inhibition of apoptosis by the sFas ligand, enhancing Fas-mediated apoptosis. Studies have demonstrated that impaired Fas-mediated apoptosis is associated with poor clinical outcomes and cancer chemoresistance $(100,101)$. Therefore, FAS-AS1 may be an important target for lymphoma diagnosis and therapy.

Changes in specific lncRNAs have been demonstrated to correlate with a wide variety of types of cancer (Table I). These findings suggest that lncRNAs are important in tumor cell activation and progression, however, the mechanism of action requires further investigation.

\section{Conclusions and future perspectives}

LncRNAs are significant in a series of biological processes, including epigenetics, the regulation of translation and post-transcriptional processing. Aberrant lncRNA expression is associated with various human diseases. Unlike protein coding genes and miRNA, the specific roles of lncRNAs remain to be fully elucidated. Aberrant lncRNA expression is involved in carcinogenesis by disrupting major biological processes, including DNA methylation in epigenetic modifications and gene silencing. However, only a small number of lncRNAs have been identified and, thus, the impact of lncRNAs in tumor development remains to be fully elucidated. Technological developments in investigating the function and mechanism of lncRNAs require further exploitation. The differential expression of IncRNAs may be a significant marker in cancer diagnosis and prognosis, and may offer potential in lncRNA-mediated targeted therapy in the future.

\section{Acknowledgements}

The present study was partly supported by the National Natural Science Foundation (grant nos. 81473486 and 
81270598), National Public Health Grand Research Foundation (grant no. 201202017), Natural Science Foundations of Shandong Province (grant nos. ZR2012HZ003 and 2009ZRB14176), Technology Development Projects of Shandong Province (grant no. 2014GSF118021,2010GSF10250 and 2008GG2NS02018), the Program of Shandong Medical Leading Talent and the Taishan Scholar Foundation of Shandong Province.

\section{References}

1. Alexander RP, Fang G, Rozowsky J, Snyder M and Gerstein MB Annotating non-coding regions of the genome. Nat Rev Genet 11: 559-571, 2010.

2. Ponting CP and Belgard TG: Transcribed dark matter: Meaning or myth? Hum Mol Genet 19 (R2): R162-R168, 2010.

3. Carninci P, Kasukawa T, Katayama S, Gough J, Frith MC, Maeda N, Oyama R, Ravasi T, Lenhard B, Wells C, et al; RIKEN Genome Exploration Research Group and Genome Science Group (Genome Network Project Core Group): The transcriptional landscape of the mammalian genome. Science 309: 1559-1563, 2005.

4. Croce CM: Causes and consequences of microRNA dysregulation in cancer. Nat Rev Genet 10: 704-714, 2009.

5. Esquela-Kerscher A and Slack FJ: Oncomirs - microRNAs with a role in cancer. Nat Rev Cancer 6: 259-269, 2006.

6. Hammond SM. MicroRNAs as tumor suppressors. Nat Genet 39: 582-583, 2007.

7. Amaral PP, Dinger ME, Mercer TR and Mattick JS: The eukaryotic genome as an RNA machine. Science 319: 1787-1789, 2008.

8. Inagaki S, Numata K, Kondo T, Tomita M, Yasuda K, Kanai A and Kageyama Y: Identification and expression analysis of putative mRNA-like non-coding RNA in Drosophila. Genes Cells 10 1163-1173, 2005.

9. Derrien T, Johnson R, Bussotti G, Tanzer A, Djebali S, Tilgner H, Guernec G, Martin D, Merkel A, Knowles DG, et al: The GENCODE v7 catalog of human long noncoding RNAs: Analysis of their gene structure, evolution, and expression. Genome Res 22: 1775-1789, 2012.

10. Ponting CP, Oliver PL and Reik W: Evolution and functions of long noncoding RNAs. Cell 136: 629-641, 2009.

11. Jonsson P, Coarfa C, Mesmar F, Raz T, Rajapakshe K, Thompson JF, Gunaratne PH and Williams C: Single-Molecule Sequencing Reveals Estrogen-Regulated Clinically Relevant IncRNAs in Breast Cancer. Mol Endocrinol 29: 1634-1645, 2015.

12. Ylipää A, Kivinummi K, Kohvakka A, Annala M, Latonen L, Scaravilli M, Kartasalo K, Leppänen SP, Karakurt S, Seppälä $\mathrm{J}$, et al: Transcriptome Sequencing Reveals PCAT5 as a Novel ERG-Regulated Long Noncoding RNA in Prostate Cancer. Cancer Res 75: 4026-4031, 2015.

13. Wapinski $\mathrm{O}$ and Chang HY: Long noncoding RNAs and human disease. Trends Cell Biol 21: 354-361, 2011

14. Zappulla DC and Cech TR: Yeast telomerase RNA: A flexible scaffold for protein subunits. Proc Natl Acad Sci U S A 101: 10024-10029, 2004.

15. Monnier P, Martinet C, Pontis J, Stancheva I, Ait-Si-Ali S and Dandolo L: H19 lncRNA controls gene expression of the Imprinted Gene Network by recruiting MBD1. Proc Natl Acad Sci U S A 110:20693-20698, 2013.

16. Caley DP, Pink RC, Trujillano D and Carter DR. Long noncoding RNAs, chromatin, and development. ScientificWorldJournal 10: 90-102, 2010

17. Cheetham SW, Gruhl F, Mattick JS and Dinger ME. Long noncoding RNAs and the genetics of cancer. Br J Cancer 108 : $2419-2425,2013$.

18. Wilusz JE, Sunwoo H and Spector DL. Long noncoding RNAs: Functional surprises from the RNA world. Genes Dev 23 : 1494-1504, 2009.

19. Pandey GK, Mitra S, Subhash S, Hertwig F, Kanduri M, Mishra K, Fransson S, Ganeshram A, Mondal T, Bandaru S, et al: The risk-associated long noncoding RNA NBAT-1 controls neuroblastoma progression by regulating cell proliferation and neuronal differentiation. Cancer Cell 25: 722-737, 2014.

20. Guttman M, Amit I, Garber M, French C, Lin MF, Feldser D, Huarte M, Zuk O, Carey BW, Cassady JP, et al: Chromatin signature reveals over a thousand highly conserved large non-coding RNAs in mammals. Nature 458: 223-227, 2009.
21. Zhang M, Gu H, Xu W and Zhou X: Down-regulation of lncRNA MALAT1 reduces cardiomyocyte apoptosis and improves left ventricular function in diabetic rats. Int J Cardiol 203: 214-216, 2015.

22. Jiang HJ, Wang $S$ and Ding Y. Emerging paradigms of long non-coding RNAs in gastrointestinal cancer. Am J Stem Cells 3: 63-73, 2014

23. Zhang H, Zeitz MJ, Wang H, Niu B, Ge S, Li W, Cui J, Wang G, Qian G, Higgins MJ, et al: Long noncoding RNA-mediated intrachromosomal interactions promote imprinting at the Kenq1 locus. J Cell Biol 204: 61-75, 2014.

24. Feng J, Bi C, Clark BS, Mady R, Shah P and Kohtz JD: The Evf-2 noncoding RNA is transcribed from the Dlx-5/6 ultraconserved region and functions as a Dlx-2 transcriptional coactivator. Genes Dev 20: 1470-1484, 2006.

25. Martianov I, Ramadass A, Serra Barros A, Chow N and Akoulitchev A: Repression of the human dihydrofolate reductase gene by a non-coding interfering transcript. Nature 445: 666-670, 2007.

26. Wang X, Arai S, Song X, Reichart D, Du K, Pascual G, Tempst P, Rosenfeld MG, Glass CK and Kurokawa R: Induced ncRNAs allosterically modify RNA-binding proteins in cis to inhibit transcription. Nature 454: 126-130, 2008.

27. Hollander MC, Alamo I and Fornace AJ Jr: A novel DNA damage-inducible transcript, gadd7, inhibits cell growth, but lacks a protein product. Nucleic Acids Res 24: 1589-1593, 1996.

28. Liu X, Li D, Zhang W, Guo M and Zhan Q: Long non-coding RNA gadd7 interacts with TDP-43 and regulates Cdk6 mRNA decay. EMBO J 31: 4415-4427, 2012.

29. Faghihi MA, Modarresi F, Khalil AM, Wood DE, Sahagan BG, Morgan TE, Finch CE, St Laurent G III, Kenny PJ and Wahlestedt $\mathrm{C}$ : Expression of a noncoding RNA is elevated in Alzheimer's disease and drives rapid feed-forward regulation of beta-secretase. Nat Med 14: 723-730, 2008.

30. Faghihi MA, Zhang M, Huang J, Modarresi F, Van der Brug MP, Nalls MA, Cookson MR, St-Laurent G III and Wahlestedt C: Evidence for natural antisense transcript-mediated inhibition of microRNA function. Genome Biol 11: R56, 2010.

31. Yoon JH, Abdelmohsen K and Gorospe M: Posttranscriptional gene regulation by long noncoding RNA. J Mol Biol 425: 3723-3730, 2013

32. Kandalepas PC and Vassar R: The normal and pathologic roles of the Alzheimer's $\beta$-secretase, BACE1. Curr Alzheimer Res 11: 441-449, 2014.

33. Kandalepas PC, Sadleir KR, Eimer WA, Zhao J, Nicholson DA and Vassar R: The Alzheimer's $\beta$-secretase BACE1 localizes to normal presynaptic terminals and to dystrophic presynaptic terminals surrounding amyloid plaques. Acta Neuropathol 126: 329-352, 2013.

34. Berger SL, Kouzarides T, Shiekhattar R and Shilatifard A: An operational definition of epigenetics. Genes Dev 23: 781-783, 2009.

35. Huang Y, Nayak S, Jankowitz R, Davidson NE and Oesterreich S: Epigenetics in breast cancer: What's new? Breast Cancer Res 13: 225, 2011.

36. Bernstein BE, Meissner A and Lander ES: The mammalian epigenome. Cell 128: 669-681, 2007.

37. Shen $H$ and Laird PW: Interplay between the cancer genome and epigenome. Cell 153: 38-55, 2013.

38. Costa FF: Epigenomics in cancer management. Cancer Manag Res 2: 255-265, 2010.

39. Cao J: The functional role of long non-coding RNAs and epigenetics. Biol Proced Online 16: 11, 2014.

40. Liu Y, Wang B, Liu X, Lu L, Luo F, Lu X, Shi L, Xu W and Liu Q: Epigenetic silencing of p21 by long non-coding RNA HOTAIR is involved in the cell cycle disorder induced by cigarette smoke extract. Toxicol Lett 240: 60-67, 2016.

41. Guil S and Esteller M: DNA methylomes, histone codes and miRNAs: Tying it all together. Int J Biochem Cell Biol 41: 87-95, 2009.

42. Sehgal L, Mathur R, Braun FK, Wise JF, Berkova Z, Neelapu S, Kwak LW and Samaniego F: FAS-antisense 1 lncRNA and production of soluble versus membrane Fas in B-cell lymphoma. Leukemia 28: 2376-2387, 2014.

43. Brannan CI, Dees EC, Ingram RS and Tilghman SM. The product of the H19 gene may function as an RNA. Mol Cell Biol 10: 28-36, 1990.

44. Moran VA, Perera RJ and Khalil AM. Emerging functional and mechanistic paradigms of mammalian long non-coding RNAs. Nucleic Acids Res 40: 6391-6400, 2012.

45. Kong L, Zhou X, Wu Y, Wang Y, Chen L, Li P, Liu S, Sun S, Ren Y, Mei M, et al: Targeting HOTAIR induces mitochondria related apoptosis and inhibits tumor growth in head and neck squamous cell carcinoma in vitro and in vivo. Curr Mol Med 15: 952-960, 2015. 
46. Cai X, Liu Y, Yang W, Xia Y, Yang C, Yang S and Liu X: Long noncoding RNA MALAT1 as a potential therapeutic target in osteosarcoma. J Orthop Res Nov: 17, 2015 (Epub ahead of print).

47. Zhu YP, Bian XJ, Ye DW, Yao XD, Zhang SL, Dai B, Zhang HL and Shen YJ: Long noncoding RNA expression signatures of bladder cancer revealed by microarray. Oncol Lett 7: 1197-1202, 2014.

48. Jemal A, Bray F, Center MM,Ferlay J, Ward E and Forman D: Global cancer statistics. CA Cancer J Clin 61: 69-90, 2011.

49. Burnett RA, Swanson Beck J, Howatson SR, Lee FD, Lessells AM, McLaren KM, Ogston S, Robertson AJ, Simpson JG and Smith GD: Observer variability in histopathological reporting of malignant bronchial biopsy specimens. J Clin Pathol 47: 711-713, 1994.

50. Rivera MP, Detterbeck F and Mehta AC; American College of Chest Physicians: Diagnosis of lung cancer: The guidelines. Chest 123 (Suppl): 129S-136S, 2003.

51. Schreiber G and McCrory DC: Performance characteristics of different modalities for diagnosis of suspected lung cancer: summary of published evidence.

52. Li Y and Wei S: Advances on mechanisms of coagulation with non-small cell lung cancer. Chin J Lung Can 16: 676-680, 2013 (In Chinese).

53. Ji P, Diederichs S, Wang W, Böing S, Metzger R, Schneider PM, Tidow N, Brandt B, Buerger H, Bulk E, et al: MALAT-1, a novel noncoding RNA, and thymosin beta4 predict metastasis and survival in early-stage non-small cell lung cancer. Oncogene 22: 8031-8041, 2003.

54. Schmidt LH, Spieker T, Koschmieder S, Schaffers S, Humberg J, Jungen D, Bulk E, Hascher A, Wittmer D, Marra A, et al: The long noncoding MALAT-1 RNA indicates a poor prognosis in non-small cell lung cancer and induces migration and tumor growth. J Thorac Oncol 6: 1984-1992, 2011.

55. Shen L, Chen L, Wang Y, Jiang X, Xia H and Zhuang Z: Long noncoding RNA MALAT1 promotes brain metastasis by inducing epithelial-mesenchymal transition in lung cancer. J Neurooncol 121: 101-108, 2015

56. Wang G, Liu C, Deng S, Zhao Q, Li T, Qiao S, Shen L, Zhang Y, Lü J, Meng L, et al: Long noncoding RNAs in regulation of human breast cancer. Brief Funct Genomics: Nov 18, 2015 (Epub ahead of print).

57. Lei B, Xu SP, Liang XS, Li YW, Zhang JF, Zhang GQ and Pang D: Long non-coding RNA MVIH is associated with poor prognosis and malignant biological behavior in breast cancer. Tumour Biol: Nov 10 2015 (Epub ahead of print).

58. Rinn JL, Kertesz M, Wang JK, Squazzo SL, Xu X, Brugmann SA, Goodnough LH, Helms JA, Farnham PJ, et al: Functional demarcation of active and silent chromatin domains in human HOX loci by noncoding RNAs. Cell 129: 1311-1323, 2007.

59. Tsai MC, Spitale RC and Chang HY: Long intergenic noncoding RNAs: New links in cancer progression. Cancer Res 71: 3-7, 2011.

60. Tsai MC, Manor O, Wan Y, Mosammaparast N, Wang JK, Lan F, Shi Y, Segal E and Chang HY: Long noncoding RNA as modular scaffold of histone modification complexes. Science 329: 689-693, 2010.

61. Liu YW, Sun M, Xia R, Zhang EB, Liu XH, Zhang ZH, Xu TP, De W, Liu BR and Wang ZX: LincHOTAIR epigenetically silences miR34a by binding to PRC2 to promote the epithelial-to-mesenchymal transition in human gastric cancer. Cell Death Dis 6: e1802, 2015.

62. Karytinos A, Forneris F, Profumo A, Ciossani G, Battaglioli E, Binda $\mathrm{C}$ and Mattevi A: A novel mammalian flavin-dependent histone demethylase. J Biol Chem 284: 17775-17782, 2009.

63. Gupta RA, Shah N, Wang KC, Kim J, Horlings HM, Wong DJ, Tsai MC, Hung T, Argani P, Rinn JL, et al: Long non-coding RNA HOTAIR reprograms chromatin state to promote cancer metastasis. Nature 464: 1071-1076, 2010.

64. Sørensen KP, Thomassen M, Tan Q, Bak M, Cold S, Burton M, Larsen MJ and Kruse TA: Long non-coding RNA HOTAIR is an independent prognostic marker of metastasis in estrogen receptor-positive primary breast cancer. Breast Cancer Res Treat 142: 529-536, 2013

65. Bhan A, Hussain I, Ansari KI, Kasiri S, Bashyal A and Mandal SS: Antisense transcript long noncoding RNA (lncRNA) HOTAIR is transcriptionally induced by estradiol. J Mol Biol 425: 3707-3722, 2013.

66. Shi Y, Lu J, Zhou J, Tan X, He Y, Ding J, Tian Y, Wang L and Wang $\mathrm{K}$ : Long non-coding RNA Loc554202 regulates proliferation and migration in breast cancer cells. Biochem Biophys Res Commun 446: 448-453, 2014.

67. Augoff K, McCue B, Plow EF and Sossey-Alaoui K: miR-31 and its host gene lncRNA LOC554202 are regulated by promoter hypermethylation in triple-negative breast cancer. Mol Cancer 11: 5, 2012
68. Ren S, Liu Y, Xu W, Sun Y, Lu J, Wang F, Wei M, Shen J, Hou $\mathrm{J}$, Gao X, et al: Long noncoding RNA MALAT-1 is a new potential therapeutic target for castration resistant prostate cancer. J Urol 190: 2278-2287, 2013.

69. Prensner JR, Iyer MK, Balbin OA, Dhanasekaran SM, Cao Q, Brenner JC, Laxman B, Asangani IA, Grasso CS, Kominsky $\mathrm{HD}$, et al: Transcriptome sequencing across a prostate cancer cohort identifies PCAT-1, an unannotated lincRNA implicated in disease progression. Nat Biotechnol 29: 742-749, 2011.

70. Walsh AL, Tuzova AV, Bolton EM, Lynch TH, Perry AS. Long noncoding RNAs and prostate carcinogenesis: the missing 'linc'? Trends in molecular medicine. 2014 Aug;20(8):428-36. PubMed PMID: 24836411

71. Martens-Uzunova ES, Bottcher R, Croce CM, Jenster G, Visakorpi T, Calin GA. Long noncoding RNA in prostate, bladder, and kidney cancer. European urology. 2014 Jun;65(6):1140-51. PubMed PMID: 24373479.

72. Crawford ED, Rove KO, Trabulsi EJ, Qian J, Drewnowska KP, Kaminetsky JC, Huisman TK, Bilowus ML, Freedman SJ, Glover WL Jr and Bostwick DG: Diagnostic performance of PCA3 to detect prostate cancer in men with increased prostate specific antigen: A prospective study of 1,962 cases. J Urol 188: 1726-1731, 2012.

73. Hessels D, Klein Gunnewiek JM, van Oort I, Karthaus HF, van Leenders GJ, van Balken B, Kiemeney LA, Witjes JA and Schalken JA: DD3(PCA3)-based molecular urine analysis for the diagnosis of prostate cancer. Eur Urol 44: 8-15, 2003.

74. Crea F, Watahiki A, Quagliata L, Xue H, Pikor L, Parolia A, Wang Y, Lin D, Lam WL, Farrar WL, et al: Identification of a long non-coding RNA as a novel biomarker and potential therapeutic target for metastatic prostate cancer. Oncotarget 5: 764-774, 2014

75. Miyoshi N, Wagatsuma H, Wakana S, Shiroishi T, Nomura M, Aisaka K, Kohda T, Surani MA, Kaneko-Ishino T and Ishino F: Identification of an imprinted gene, Meg3/Gt12 and its human homologue MEG3, first mapped on mouse distal chromosome 12 and human chromosome 14q. Genes Cells 5: 211-220, 2000.

76. Zhou Y, Zhang X and Klibanski A: MEG3 noncoding RNA: A tumor suppressor. J Mol Endocrinol 48: R45-R53, 2012.

77. Zhou Y, Zhong Y, Wang Y, Zhang X, Batista DL, Gejman R, et al: Activation of $\mathrm{p} 53$ by MEG3 non-coding RNA. J Biol Chem 282: 24731-24742, 2007.

78. Benetatos L, Hatzimichael E, Dasoula A, Dranitsaris G, Tsiara S, Syrrou M, Georgiou I and Bourantas KL: CpG methylation analysis of the MEG3 and SNRPN imprinted genes in acute myeloid leukemia and myelodysplastic syndromes. Leuk Res 34: 148-153, 2010.

79. Durinck K, Goossens S, Peirs S, Wallaert A, Van Loocke W, Matthijssens F, Pieters T, Milani G, Lammens T, Rondou P, et al: Novel biological insights in T-cell acute lymphoblastic leukemia. Exp Hematol 43: 625-639, 2015.

80. Zhang $\mathrm{L}, \mathrm{Xu} \mathrm{HG}$ and Lu C. A novel long non-coding RNA T-ALL-R-LncR1 knockdown and Par-4 cooperate to induce cellular apoptosis in T-cell acute lymphoblastic leukemia cells. Leuk Lymphoma 55: 1373-1382, 2014

81. Roussigne M, Cayrol C, Clouaire T, Amalric F and Girard JP: THAP1 is a nuclear proapoptotic factor that links prostate-apoptosis-response-4 (Par-4) to PML nuclear bodies. Oncogene 22: 2432-2442, 2003.

82. Zhang X, Weissman SM and Newburger PE: Long intergenic non-coding RNA HOTAIRM1 regulates cell cycle progression during myeloid maturation in NB4 human promyelocytic leukemia cells. RNA Biol 11: 777-787, 2014

83. Zhao H, Zhang X, Frazão JB, Condino-Neto A and Newburger PE: HOX antisense lincRNA HOXA-AS2 is an apoptosis repressor in all trans retinoic acid treated NB4 promyelocytic leukemia cells. J Cell Biochem 114: 2375-2383, 2013.

84. Zhang X, Lian Z, Padden C, Gerstein MB, Rozowsky J, Snyder M, Gingeras TR, Kapranov P, Weissman SM and Newburger PE: A myelopoiesis-associated regulatory intergenic noncoding RNA transcript within the human HOXA cluster. Blood 113: 2526-2534, 2009.

85. Walczak H, Miller RE, Ariail K, Gliniak B, Griffith TS, Kubin M, Chin W, Jones J, Woodward A, Le T, et al: Tumoricidal activity of tumor necrosis factor-related apoptosis-inducing ligand in vivo. Nat Med 5: 157-163, 1999.

86. Sun J, Li W, Sun Y, Yu D, Wen X, Wang H, Cui J, Wang G, Hoffman AR and Hu JF: A novel antisense long noncoding RNA within the IGF1R gene locus is imprinted in hematopoietic malignancies. Nucleic Acids Res 42: 9588-9601, 2014. 
87. Chapuis N, Tamburini J, Cornillet-Lefebvre P, Gillot L Bardet V, Willems L, Park S, Green AS, Ifrah N, Dreyfus F, et al Autocrine IGF-1/IGF-1R signaling is responsible for constitutive PI3K/Akt activation in acute myeloid leukemia: Therapeutic value of neutralizing anti-IGF-1R antibody. Haematologica 95: 415-423, 2010.

88. Grandage VL, Gale RE, Linch DC and Khwaja A: PI3-kinase/Akt is constitutively active in primary acute myeloid leukaemia cells and regulates survival and chemoresistance via NF-kappaB, Mapkinase and p53 pathways. Leukemia 19: 586-594, 2005.

89. Girnita A, All-Ericsson C, Economou MA, Aström K, Axelson M, Seregard S, Larsson O and Girnita L.: The insulin-like growth factor-I receptor inhibitor picropodophyllin causes tumor regression and attenuates mechanisms involved in invasion of uveal melanoma cells. Acta Ophthalmol 86: 26-34, 2008.

90. Delafontaine P, Song YH and Li Y: Expression, regulation, and function of IGF-1, IGF-1R, and IGF-1 binding proteins in blood vessels. Arterioscler Thromb Vasc Biol 24: 435-444, 2004.

91. Roy M, Sarkar R, Mukherjee A and Mukherjee S: Inhibition of crosstalk between Bcr-Abl and PKC signaling by PEITC, augments imatinib sensitivity in chronic myelogenous leukemia cells. Chem Biol Interact 242: 195-201, 2015.

92.Heisterkamp N and Groffen J: Molecular insights into the Philadelphia translocation. Hematol Pathol 5: 1-10, 1991

93. Bartram CR, de Klein A, Hagemeijer A, van Agthoven T, Geurts van Kessel A, Bootsma D, Grosveld G, Ferguson-Smith MA, Davies T, Stone M, et al: Translocation of c-ab1 oncogene correlates with the presence of a Philadelphia chromosome in chronic myelocytic leukaemia. Nature 306: 277-280, 1983.

94. Cilloni D and Saglio G. Molecular pathways: BCR-ABL. Clin Cancer Res 18: 930-937, 2012

95. Guo G, Qiu X, Wang S, Chen Y, Rothman PB, Wang Z, Chen Y, Wang G and Chen JL: Oncogenic E17K mutation in the pleckstrin homology domain of AKT1 promotes v-Abl-mediated pre-B-cell transformation and survival of Pim-deficient cells. Oncogene 29: 3845-3854, 2010.

96. Yang J, Wang J, Chen K, Guo G, Xi R, Rothman PB, Whitten D, Zhang L, Huang S and Chen JL: eIF4B phosphorylation by pim kinases plays a critical role in cellular transformation by $\mathrm{Abl}$ oncogenes. Cancer Res 73: 4898-4908, 2013.

97. Guo G, Kang Q, Zhu X, Chen Q, Wang X, Chen Y, Ouyang J, Zhang L, Tan H, Chen R, et al: A long noncoding RNA critically regulates Bcr-Abl-mediated cellular transformation by acting as a competitive endogenous RNA. Oncogene 34: 1768-1779, 2015.

98. Dengler MA, Staiger AM, Gutekunst M, Hofmann U, Doszczak M, Scheurich P, Schwab M, Aulitzky WE and van der Kuip H: Oncogenic stress induced by acute hyper-activation of Bcr-Abl leads to cell death upon induction of excessive aerobic glycolysis. PLoS One 6: e25139, 2011.

99.Danisz K and Blasiak J: Role of anti-apoptotic pathways activated by BCR/ABL in the resistance of chronic myeloid leukemia cells to tyrosine kinase inhibitors. Acta Biochim Pol 60: 503-514, 2013.

100. Friesen C, Herr I, Krammer PH and Debatin KM: Involvement of the CD95 (APO-1/FAS) receptor/ligand system in drug-induced apoptosis in leukemia cells. Nat Med 2: 574-577, 1996.

101. Eichhorst ST, Müerköster S, Weigand MA and Krammer PH: The chemotherapeutic drug 5-fluorouracil induces apoptosis in mouse thymocytes in vivo via activation of the CD95(APO-1/Fas) system. Cancer Res 61: 243-248, 2001

102. Yap KL, Li S, Muñoz-Cabello AM, Raguz S, Zeng L, Mujtaba S, Gil J, Walsh MJ and Zhou MM: Molecular interplay of the noncoding RNA ANRIL and methylated histone H3 lysine 27 by polycomb CBX7 in transcriptional silencing of INK4a. Mol Cell 38: 662-674, 2010.

103. Iacobucci I, Sazzini M, Garagnani P, Ferrari A, Boattini A, Lonetti A, Papayannidis C, Mantovani V, Marasco E, Ottavian $\mathrm{E}$, et al: A polymorphism in the chromosome 9p21 ANRIL locus is associated to Philadelphia positive acute lymphoblastic leukemia. Leuk Res 35: 1052-1059, 2011

104.Zhang EB, Kong R, Yin DD, You LH, Sun M, Han L, Xu TP, Xia R, Yang JS, De W, et al: Long noncoding RNA ANRIL indicates a poor prognosis of gastric cancer and promotes tumor growth by epigenetically silencing of $\mathrm{miR}-99 \mathrm{a} / \mathrm{miR}-449 \mathrm{a}$. Oncotarget 5: 2276-2292, 2014.

105. Korneev SA, Korneeva EI, Lagarkova MA, Kiselev SL, Critchley G and O'Shea M: Novel noncoding antisense RNA transcribed from human anti-NOS2A locus is differentially regulated during neuronal differentiation of embryonic stem cells. RNA 14: 2030-2037, 2008.
106. Iacoangeli A, Lin Y, Morley EJ, Muslimov IA, Bianchi R, Reilly J, Weedon J, Diallo R, Böcker W and Tiedge H: BC200 RNA in invasive and preinvasive breast cancer. Carcinogenesis 25: 2125-2133, 2004.

107. Chen W, Böcker W, Brosius J and Tiedge H: Expression of neural BC200 RNA in human tumours. J Pathol 183: 345-351, 1997.

108. Sosińska P, Mikuła-Pietrasik J and Ksiażek K: The double-edged sword of long non-coding RNA: The role of human brain-specific BC200 RNA in translational control, neurodegenerative diseases, and cancer. Mutat Res Rev Mutat Res 766: 58-67, 2015.

109. Pickard MR, Mourtada-Maarabouni M and Williams GT: Long non-coding RNA GAS5 regulates apoptosis in prostate cancer cell lines. Biochim Biophys Acta 1832: 1613-1623, 2013.

110. Yin D, He X, Zhang E, Kong R, De W and Zhang Z: Long noncoding RNA GAS5 affects cell proliferation and predicts a poor prognosis in patients with colorectal cancer. Med Oncol 31: 253, 2014.

111. Qiao HP, Gao WS, Huo JX and Yang ZS: Long non-coding RNA GAS5 functions as a tumor suppressor in renal cell carcinoma. Asian Pac J Cancer Prev 14: 1077-1082, 2013.

112. Lu X, Fang Y, Wang Z, Xie J, Zhan Q, Deng X, Chen H, Jin J, Peng $\mathrm{C}, \mathrm{Li} \mathrm{H}$, et al: Downregulation of gas 5 increases pancreatic cancer cell proliferation by regulating CDK6. Cell Tissue Res 354: 891-896, 2013.

113. Mourtada-Maarabouni M and Williams GT: Role of GAS5 noncoding RNA in mediating the effects of rapamycin and its analogues on mantle cell lymphoma cells. Clin Lymphoma Myeloma Leuk 14: 468-473, 2014.

114. Chiyomaru T, Yamamura S, Fukuhara S, Yoshino H, Kinoshita T, Majid S, Saini S, Chang I, Tanaka Y, Enokida H, et al: Genistein inhibits prostate cancer cell growth by targeting miR-34a and oncogenic HOTAIR. PLoS One 8: e70372, 2013.

115. Yan TH, Lu SW, Huang YQ, Que GB, Chen JH, Chen YP, Zhang $\mathrm{HB}$, Liang XL and Jiang JH: Upregulation of the long noncoding RNA HOTAIR predicts recurrence in stage Ta/T1 bladder cancer. Tumour Biol 35: 10249-10257, 2014.

116. Chiyomaru T, Fukuhara S, Saini S, Majid S, Deng G, Shahryari V, Chang I, Tanaka Y, Enokida H, Nakagawa M, et al: Long non-coding RNA HOTAIR is targeted and regulated by miR-141 in human cancer cells. J Biol Chem 289: 12550-12565, 2014.

117. Lee NK, Lee JH, Park CH, Yu D, Lee YC, Cheong JH, Noh SH and Lee SK: Long non-coding RNA HOTAIR promotes carcinogenesis and invasion of gastric adenocarcinoma. Biochem Biophys Res Commun 451: 171-178, 2014.

118. Wu ZH, Wang XL, Tang HM, Jiang T, Chen J, Lu S, Qiu GQ, Peng ZH and Yan DW: Long non-coding RNA HOTAIR is a powerful predictor of metastasis and poor prognosis and is associated with epithelial-mesenchymal transition in colon cancer. Oncol Rep 32: 395-402, 2014

119. Wang CM, Wu QQ, Li SQ, Chen FJ, Tuo L, Xie HW, Tong YS, Ji L, Zhou GZ, Cao G, et al: Upregulation of the long non-coding RNA PlncRNA-1 promotes esophageal squamous carcinoma cell proliferation and correlates with advanced clinical stage. Dig Dis Sci 59: 591-597, 2014.

120. Cui Z, Ren S, Lu J, Wang F, Xu W, Sun Y, Wei M, Chen J, Gao X, $\mathrm{Xu} \mathrm{C}$, et al: The prostate cancer-up-regulated long noncoding RNA PlncRNA-1 modulates apoptosis and proliferation through reciprocal regulation of androgen receptor. Urol Oncol 31: 1117-1123, 2013

121.Luo M, Li Z, Wang W, Zeng Y, Liu Z and Qiu J: Upregulated H19 contributes to bladder cancer cell proliferation by regulating ID2 expression. FEBS J 280: 1709-1716, 2013.

122. Barsyte-Lovejoy D, Lau SK, Boutros PC, Khosravi F, Jurisica I, Andrulis IL, Tsao MS and Penn LZ: The c-Myc oncogene directly induces the H19 noncoding RNA by allele-specific binding to potentiate tumorigenesis. Cancer Res 66: 5330-5337, 2006

123. Hibi K, Nakamura H, Hirai A, Fujikake Y, Kasai Y, Akiyama S, Ito $\mathrm{K}$ and Takagi $\mathrm{H}$ : Loss of $\mathrm{H} 19$ imprinting in esophageal cancer. Cancer Res 56: 480-482, 1996.

124. Zhang EB, Han L, Yin DD, Kong R, De W and Chen J: c-Myc-induced, long, noncoding H19 affects cell proliferation and predicts a poor prognosis in patients with gastric cancer. Med Oncol 31: 914, 2014

125. Sun M, Xia R, Jin F, Xu T, Liu Z, De W and Liu X: Downregulated long noncoding RNA MEG3 is associated with poor prognosis and promotes cell proliferation in gastric cancer. Tumour Biol 35: 1065-1073, 2014 